\title{
Stimulating Effect of a Newly Synthesized Sulfonamido-Basedgallate on Articular Chondrocytes in Vitro
}

\author{
Zhenhui Lu,b Liqin Wang ${ }^{a}$ Hongmei Pan ${ }^{d}$ Xiao Line,f Cuiwu Lin ${ }^{e}$ Buming Liu ${ }^{f}$ \\ Li Zheng ${ }^{a, b}$ Jinmin Zhao ${ }^{b}$ \\ aThe Medical and Scientific Research Center, Guangxi Medical University, Nanning, ${ }^{\mathrm{b}}$ Guangxi Key \\ Laboratory of Regenerative Medicine, Guangxi Medical University, Nanning, 'Department of Radiology, \\ The First Affiliated Hospital, Sun Yat-Sen University, Guangzhou, dDepartment of Pharmacy, The Second \\ People's Hospital of Nanning, Nanning, eGuangxi Key Laboratory of Traditional Chinese Medicine \\ Quality Standards, Guangxi Institute of Traditional Medical and Pharmaceutical Sciences, Nanning, \\ fSchool of Chemistry and Chemical Engineering, Guangxi University, Nanning, China
}

Key Words

Gallic acid $\cdot$ Sulfadimoxine $\cdot$ Dedifferentiation $\cdot$ Chondrocytes $\bullet$ Phenotype maintenances

\begin{abstract}
Background: The phenotype of chondrocyte is easy to be lost when expanded in vitro by a process defined "dedifferentiation". Traditional growth factors such as transforming growth factor (TGF- $\beta 1$ ) are effective in preventing of dedifferentiation, but high costs and loss of activity limited their use. It is of significance to find substitutes which can reduce dedifferentiation and preserve chondrocytes phenotype to ensure sufficient differentiated cells for further study. Methods: We synthesized new type of sulfonamido-based gallates named ZXHA-C and investigated its effect on primary articular chondrocytes of rats. After preliminary screening by cytotoxicity test, ZXHA-C of $1.06 \times 10^{-8}, 1.06 \times 10^{-7}$ and $1.06 \times 10^{-6} \mathrm{M}$ were chosen for further studies. Cell proliferation, morphology, viability, GAG synthesis and cartilage specific gene expression were detected. Also the effects of ZXHA-C on Wnt/ $\beta$-catenin signaling pathway were investigated. Results: ZXHA-C could significantly promote chondrocytes growth. And it could enhance ECM synthesis by up-regulating expression levels of cartilage specific markers like aggrecan, collagen II and Sox9. Expression of collagen I which marked chondrocytes dedifferentiation was also significantly down-regulated after treated by ZXHA-C. Further exploration of the molecular mechanism indicated that ZXHA-C activated the Wnt/ $\beta$-catenin signal pathway in chondrocytes, as evidenced by up-regulated gene expression of $\beta$-catenin, Wnt-4, cyclin D1 and Frizzled-2 and decreased glycogen synthase kinase $3 \beta$ (GSK-3ß). Among the various concentrations, ZXHA-C of $1.06 \times 10^{-7} \mathrm{M}$ showed the best performance, which was close to positive control (group with TGF- $\beta 1$ ). Conclusion: ZXHA-C might be potential a novel agent for the maintenances of chondrocytes phenotype.
\end{abstract}

Copyright (C) 2015 S. Karger AG, Basel

L. Wang and H. Pan contributed equally to this work.

Li Zheng

KARGER 125

The Medical and Scientific Research Center, Guangxi Medical University, Nanning 530021 (China); Department of Radiology, The First Affiliated Hospital, Sun Yat-Sen University, Guangzhou 510080, (Chiana); Guangxi Key Laboratory of Regenerative Medicine, Guangxi Medical University, Nanning 530021, (China); E-Mail zhengli224@163.com 


\section{Cellular Physiology Cell Physiol Biochem 2015;37:1196-1209 \begin{tabular}{l|l} 
and $10.1159 / 000430243$ & \\
and Biochemistry Published online: September 30, 2015 & $\begin{array}{l}\text { 2015 S. Karger AG, Basel } \\
\text { www.karger.com/cpb }\end{array}$ \\
\cline { 2 - 3 }
\end{tabular}}

\section{Introduction}

Articular cartilage has limited regenerative capacity after injury. Approaches based on chondrocytes implantation are useful tools for cartilage regeneration [1,2]. Since only a small amount of cartilage can be harvested at the donor site, isolated chondrocytes should be expanded in vitro to obtain sufficient cells for clinical application [3, 4]. However, chondrocytes have a tendency to dedifferentiate as a result of the cytoskeleton modification when cultured in monolayer $[5,6]$.Dedifferentiated chondrocytes were characterized as a decrease of the production of type II collagen, which may lead to the formation of an inferior quality engineered cartilage when implanted in the cartilage defect [7]. To retain the phenotype and accelerate the proliferation of chondrocytes cultured in vitro, lots of growth factors like transforming growth factor (TGF- $\beta$ ) are employed. But the high cost, loss of activity and rapid degradation of growth factors limited their application in clinic. Therefore, to find low-cost and stable agents to substitute growth factors is of significance.

Most anti-oxidant and anti-inflammatory agents have the ability to enhance chondrocyte proliferation and matrix secretion besides of their protective effects on osteoarthritis (OA) $[8,9]$, application of which may retain the phenotype and accelerate the proliferation of chondrocytes. Gallic acid (GA) and its derivatives are a group of polyphenol compounds that with strong anti-oxidant effect, and have been known to impact several pharmacological and biochemical pathways [10]. It was reported that alyophilized extract of wine which contains large amounts of phenolic components have the protective effects in cartilage alteration [11]. However, bioactivity of GA was compromised because it is much more hydrophilic than its esters, resulting in much weaker anti-oxidant effect than its esters in cell systems [10]. It was reported that GA suppressed the proliferation of cells [12]. This may be attributed to its inhibition of Wnt/ $\beta$-catenin signaling pathway [13] which plays a key role in the processes of cell proliferation [14].

As an alternative, to couple some lipophilic compounds may improve the bioactivity of GA and broaden its application. Several derivatives of GA showed excellent biological properties. GA-based indanone derivatives exhibited no toxicity to human erythrocytes even at higher concentrations [15]. Epigallocatechin-3-gallate (EGCG), a derivative of GA, enhances aggrecan and type II collagen synthesis and ameliorates IL-1 $\beta$-mediated suppression of TGF- $\beta 1$ synthesis in human chondrocytes [16].

Recently, Nuti etal. reported a series of new $\mathrm{N}$-isopropoxy-arylsulfonamide hydroxamate inhibitors which contain several phenyl and sulfonamide group were proved to be effective in inhibiting vivo cartilage degradation [17]. This implied that incorporate sulfonamides to GA may enhance the bioactivity and therefore accelerate the growth of chondrocytes. In this study, we synthesized sulfonamido-based gallate - ZXHA-C and investigated its chondroprotective effect by detecting the cell proliferation, cell viability, DNA and GAG content and expression of cartilage specific markers. A positive control (TGF- $\beta 1$ ) comparison of ZXHA-C was also performed.

\section{Materials and Methods}

Synthesis of ZXHA-C

Electrospray ionization mass spectrum (ESI-MS) was recorded on a Shimadzu LC-MS $2010 \mathrm{~A} .{ }^{1} \mathrm{Hand}{ }^{13} \mathrm{C}$ NMR spectra were obtained from a Bruker Advance III 300 at 400 and $125 \mathrm{MHz}$, respectively.

Acetic acid 2, 3-diacetoxy-5-[4-(5, 6-dimethoxy-pyrimidin-4-ylsulfamoyl)-phenylcarbamoyl]phenylester (ZXHA-C) was prepared from GA and sulfadimoxine. The synthetic route is presented in Fig. 1 in detail. GA and acetyl oxide in the oil bath $\left(120^{\circ} \mathrm{C}\right)$ reflux reacted for $6-10 \mathrm{~h}$. Reaction products with $\mathrm{SOCl}_{2}$ in oil bath $\left(80^{\circ} \mathrm{C}\right)$ reflux reacted for $5 \mathrm{~h}$, then rotary evaporation $\mathrm{SOCL}_{2}$. With sulfadimoxin (1:1), THF, pyridine, ice bath for $12 \mathrm{~h}$. After reactions, appropriate distilled water was added to the mixture, and then the raw product precipitated was separated by vacuum filtration. The raw product was recrystallized in a

\section{KARGER}




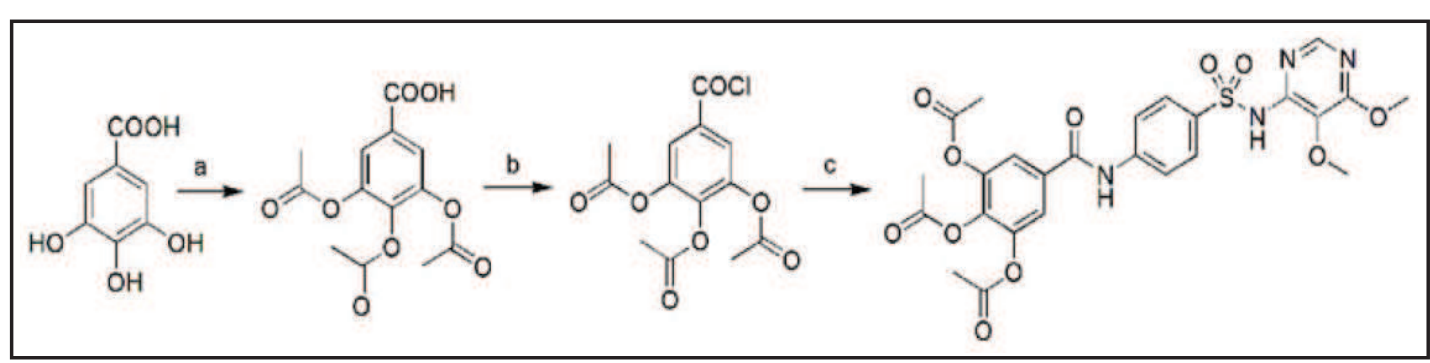

Fig. 1. Reagents and conditions: (a) Acetyl oxide, oil bath, $120^{\circ} \mathrm{C}$ (b) $\mathrm{SOCl}$, oil bath, $80^{\circ} \mathrm{C}$ (c) Sulfadimoxine, THF, Pyridine, ice bath.

THF-methanol solvent system. The purity of ZXHA-C is greater than 95\% detected by TLC (In three different development system only one spot appeared) and HPLC analysis.

\section{Positive control}

Human transforming growth factor (TGF- $\beta 1$, PEPROTECH, USA) was used as the positive control, and its purity is greater than $98 \%$ that detected by SDS-PAGE gel and HPLC analyses.

\section{Articular cartilage cells culture}

Joint hyaline cartilage was isolated from new-born Sprague-Dawley (SD) rats by enzymatic digestion with $0.25 \%$ trypsin (Solarbio, China) for $30 \mathrm{~min}$ and then with $2 \mathrm{mg} / \mathrm{mL}$ collagenase type II (Gibco, USA) in Minimum Essential Medium Alpha ( $\alpha$-MEM,Gibco, USA) for $3 \mathrm{~h}$. After centrifuge (1000 rpm, $5 \mathrm{~min}$ ), cells were re-suspended in a basal culture medium of $\alpha$-MEM containing 10\% Fetal Bovine Serum(FBS, Gibco, USA) and $1 \%$ antibiotics (penicillin $100 \mathrm{U} / \mathrm{mL}$, streptomycin $100 \mathrm{U} / \mathrm{mL}$ ). The culture medium was changed every 2 days. Culture conditions in an incubator (Thermo Fisher Scientific, UK) at 5\% $\mathrm{CO} 237^{\circ} \mathrm{C}$ humidified atmosphere. Cells were passaged when the confluence reached to 80 90\%. Chondrocytes of passage one were used for further studies. This study was approved by the Institutional Ethical Committee of Guangxi Medical University (approval no. 20131221) and was conducted in accordance with the guidelines of US for laboratory animal use and care.

\section{ZXHA-C treatment}

ZXHA-C was dissolved in sodium hydroxide solution ( $\mathrm{NaOH}$, Sigma, USA) of $0.1 \mathrm{mg} / \mathrm{mL}$ as stock solution and stored at $4^{\circ} \mathrm{C}$. The stock solution of ZXHA-C was then added to the cell cultures medium to provide various concentrations. Culture medium containing various concentrations of ZXHA-C was replaced every 3 days. Also a negative control that with only fresh culture media and a positive control with $15 \mathrm{ng} /$ mL TGF- $\beta 1$ were carried out.

\section{Cytotoxicity test}

The cytotoxicity of ZXHA-C on chondrocytes was performed by the3-(4, 5)-dimethylthiahiazo (-zy1)-3, 5-di-phenytetrazolium-romide (MTT, Gibco, USA) method. Chondrocytes were trypsinized by $0.25 \%$ trypsin/ETDA (Solarbio, China) when the cells of first passage reached to $60 \% \sim 70 \%$ confluence. After centrifuged, cells were re-suspended with fresh medium and counted by a hemocytometer, then seeded on 96-plates. The final cell number in each well was $5 \times 10^{3}$. Concentrations of ZXHA-C ranged from $1.06 \times 10^{-10}$ $\mathrm{M} \sim 54.5 \times 10^{-3} \mathrm{M}$ were treated with chondrocytes.

After 3 days of culture, cytotoxicity test was carried out by MTT analysis. Briefly, a solution of MTT in PBS was added into each well with the final concentration of $5 \mathrm{mg} / \mathrm{mL}$ then incubated at $37^{\circ} \mathrm{C}$ for $4 \mathrm{~h}$. After the medium was removed, $200 \mu \mathrm{L}$ dimethylsulfoxide (DMSO, Sigma) was added, which was used to dissolve MTT formazan formed by metabolically viable cells. The absorbance was detected by a microplate reader (Thermo Fisher Scientific, UK) at $570 \mathrm{~nm}$. All experiments were performed in five times.

\section{Cell viability assay}

The viability of chondrocytes was determined by fluorescein diacetate (FDA, GenwayBiotech,Inc, USA)/propidium iodide (PI, Sigma, USA) staining at day 2, 4 and 6 respectively. Briefly, the stock solutions 


\section{Cellular Physiology Cell Physiol Biochem 2015;37:1196-1209 \begin{tabular}{ll|l} 
and Biochemistry & $\begin{array}{l}\text { DOI: 10.1159/000430243 } \\
\text { Published online: September 30, } 2015\end{array}$ & $\begin{array}{l}\text { c } 2015 \text { S. Karger AG, Basel } \\
\text { www.karger.com/cpb }\end{array}$ \\
\hline
\end{tabular}}

Lu et al.: ZXHA-C Exert Chondro-Protective Effect

of FDA and PI were added to the cells at a final concentration of $2 \mu \mathrm{mol} / \mathrm{L}$ and $2 \mu \mathrm{g} / \mathrm{L}$ respectively and incubated in the dark for $5 \mathrm{~min}$ at $37^{\circ} \mathrm{C}$. Images were captured via a laser scanning confocal microscope (Nikon A1, Japan).

\section{Cell Morphological Analysis}

After being culture alone or with different concentrations of ZXHA-C or TGF- $\beta 1$ for 2,4 and 6 days, the cells were washed by PBS for three times and fixed with $95 \%$ alcohol for $30 \mathrm{~min}$. Then the cells were washed by PBS again and stained with hematoxylin and eosin kit (HE, JianChengBiotech, China) to observe the morphology of chondrocytes. Images were photographed by an inverted phase contrast microscope (Zeiss Corporation, German).

Samples in all groups were permeabilized using 0.5\% Triton X-100 (Sigma Aldrich, USA), with 1\% BSA (Santa Cruz Biotechnology Inc, Santa Cruz, CA, USA) as a blocking buffer for $30 \mathrm{~min}$ at $37^{\circ} \mathrm{C}$. Cells were stained for $30 \mathrm{~min}$ at room temperature with rhodamine phalloidin (Invitrogen,USA), following by Hoechst 33258 (Beyotime, USA) for 5 min to visualize nuclei. Imaging was performed using a scanning confocal microscope (Nikon A1, Japan).

\section{Cell proliferation analysis and Biochemical assay}

After cultured for 2, 4 and 6 days respectively, chondrocytes were washed by PBS, and then digested with $0.25 \%$ trypsin /ETDA. Cells were centrifuged and then re-suspended in PBS containing $60 \mu \mathrm{g} / \mathrm{mL}$ proteinase K (Sigma, USA) for $16 \mathrm{~h}$ at $60^{\circ} \mathrm{C}$. The DNA content was determined by spectrofluorometer using Hoechst 33258 (Sigma, USA) dye at $460 \mathrm{~nm}$ with calf thymus DNA as standard and the absorption of Hoechst 33258 dye as the baseline [18]. The total secretion of glycosaminoglycan (GAG) was measured using 1, 9-Dimethylmethylene Blue (DMMB, SIGMA-ALORICH, USA) with chondroitin sulphate (Sigma, USA) as standard at $525 \mathrm{~nm}$. The GAG content was quantified on standard curve and accordingly normalized to the total DNA content. All the experiments were carried out in sextuplicate.

\section{RNA extraction and $q R T-P C R$ analysis}

The qRT-PCR was to analysis the gene expression of aggrecan, sox9, collagen I, II and X. The primer sequences and genbank accession numbers used for qRT-PCR are summarized in Table 1. Chondrocytes were seeded in 6-well plates and cultured alone or with ZXHA-C at concentrations of $1.06 \times 10^{-8}, 1.06 \times$ $10^{-7}, 1.06 \times 10^{-6} \mathrm{M}$ or $15 \mathrm{ng} / \mathrm{mL}$ TGF- $\beta 1$. After 2,4 and 6 days, total RNA was successively extracted with a Total Isolation RNA kit (Invitrogen Corporation, CA, USA) according to the instructions of manufactures. Reverse transcription of RNA was carried out at $25^{\circ} \mathrm{C}$ for $5 \mathrm{~min}, 42^{\circ} \mathrm{C}$ for $60 \mathrm{~min}$ and then $72^{\circ} \mathrm{C}$ for $5 \mathrm{~min}$ using a Reverse Transcription kit (Fermentas Company, USA). The qRT-PCR reactions were performed using a Quantitative PCR Detection System (Eppendorf Corporation, USA) with a Fast Start Universal SYBR Green Master (Mix, Roche Company, Germany) under the condition of $10 \mathrm{~min}$ at $95^{\circ} \mathrm{C}, 15 \mathrm{~s}$ at $95^{\circ} \mathrm{C}$ and $1 \mathrm{~min}$ at

Table 1. Primer sequences used in qRT-PCR experiments

\begin{tabular}{lll}
\hline Gene name & \multicolumn{1}{c}{ Forward primer } & \multicolumn{1}{c}{ Reverse primer } \\
\hline B-actin & 5'-CCCATCTATGAGGGTTACGC -3' & 5'-TTTAATGTCACGCACGATTTC -3' \\
Aggrecan & 5'- CCGCTGGTCTGATGGACACT -3' & 5'-AGGTGTTGGGGTCTGTGCAA -3' \\
Collagen II & 5'-CTGGTCCTTCCGGCCCTAGA -3' & 5'-GGATCGGGGCCCTTCTCTCT -3' \\
Sox9 & 5'-TCCAGCAAGAACAAGCCACA-3' & 5'-CGAAGGGTCTCTTCTCGCTC -3' \\
Collagen I & 5'-CATGAGCCGAAGCTAACCC -3'-3' & 5'-CTCCTATGACTTCTGCGTCTGG -3' \\
Collagen X & 5'- TCTGCTGCTAGTGTCCTTGACG -3' & 5'-GGAATGCCTTGTTCTCCTCTTACT -3' \\
-catenin & 5'-AAG GAA GCT TCC AGA CAT GC-3' & 5'-AGC TTG CTC TCT TGA TTG CC-3' \\
Frizzled-2 & 5'-TCG AGG CCA ATT CGC AGT A-3' & 5'-CAG GAA GGA TGT GCC GAT G-3' \\
cyclin D1 & 5'-AAT GCC AGA GGC GGA TGA GA-3' & 5'-GCT TGT GCG GTA GCA GGA GA-3' \\
Wnt-4 & 5'-TCA GCC CAC AGG GTT TCC A-3' & 5'-CGC TCG CCA GCA TGT CTT T-3' \\
GSK-3 3 & 5'-AAA GTG CAT CGC TGG CTT A-3' & 5'-GTC GAC GGT TTG TTT CCA AT-3' \\
\hline
\end{tabular}




\section{Cellular Physiology Cell Physiol Biochem 2015;37:1196-1209

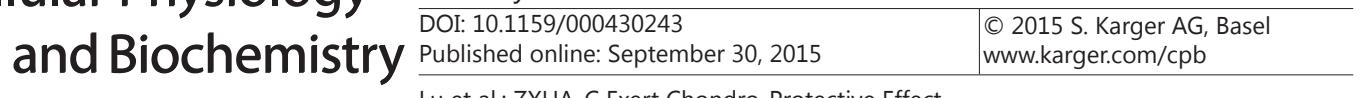 \\ Lu et al.: ZXHA-C Exert Chondro-Protective Effect}

$60^{\circ} \mathrm{C}$. The dissociation curve of each primer pair was analyzed to confirm the primer specificity. Marker gene expression of chondrocytes was analyzed by the $2^{-\Delta \Delta \mathrm{CT}}$ method using $\beta$-actin. The experiments were repeated for triplicate and each sample was repeated three times for each gene.

\section{Safranin $O$ staining}

Safranin 0 staining was scored for glycosaminoglycans (GAGs) secretion. The cells were fixed with $95 \%$ acohol for $30 \mathrm{~min}$ and then stained with $0.1 \%$ safranin O (Sigma, USA) for $10 \mathrm{~min}$. Subsequently, cells were rinsed with water and sealed with neutral gum. Finally, the cells were observed and photographed under an inverted phase contrast microscope equipped with a computer (Zeiss Corporation, German).

\section{Immunohistochemical examination}

For immunohistochemical examination, monoclonal antibody to type I collagen (Boster, China), type II collagen (Boster, China) and $\beta$-catenin (Boster, China) were used according to the instructions of manufacture. $4 \%$ paraformaldehyde-fixed, TritonX-100-permeabilized, $3 \% \mathrm{H}_{2} \mathrm{O}_{2}$ - incubated cells were blocked with normal goat serum for $10 \mathrm{~min}$ at room temperature. Cells were incubated with a primary antibody at a dilution of 1:200 for $2 \mathrm{~h}$. Whereafter, second antibody and biotin labeled horseradish peroxidase were added. Subsequently, 3'-diaminobenzidine tetrahydrochloride (DAB) kit (Boster, China) was used according to the instructions with cells counterstained with haematoxylin. Finally, cells were gradually dehydrated and sealed with neutral gum. An inverted phase contrast microscope (Zeiss Corporation, German) was used to evaluate and photograph the cells.

Statistical Analysis

Results were demonstrated as mean \pm SD. Statistical significance was determined using one way analysis of variance (ANOVA) followed by Dunnett's post hoc test. The level of significance was set to $\mathrm{P}<0.05$.

\section{Results}

The synthesis routes of GA and sulfadimoxine sodium was shown in Fig. 1. ZXHA-C with the following properties: MS-ESI: $\mathrm{m} / \mathrm{z}: 1 \mathrm{H}$ NMR (400 MHz, DMSO) $\delta 11.10(\mathrm{~s}, 1 \mathrm{H}$, -SO2-NH),10.69 (s, 1H, -CO-NH), 8.11 (s, 1H, Py-H), 7.99-7.92 (dd, J = 8.9 Hz, 4H, Ar-H), 7.81 (s, 2H,Ar-H), 3.88 (s, 3H, -OCH3), 3.69 (s, 3H, -OCH3), 2.33 (s, 6H, -CH3), 2.31 (s, 6H, 2×-CH3).13C-NMR (125 MHz, DMSO) $\delta 168.05,166.99,163.72,161.67,150.42,143.22$, $142.78,137.67,132.48,128.67,127.33,120.79,119.82,60.29,54.10,20.35,19.90$.

The cytotoxicity of ZXHA-C on chondrocytes was detected by MTT assay. Articular cartilage cells of SD rats were treated with ZXHA-C of various concentrations $\left(1.06 \times 10^{-}\right.$ $10 \sim 54.5 \times 10^{-3} \mathrm{M}$ ). As shown in Fig. 2A, ZXHA-C ranged from $1.06 \times 10^{-10}$ to $1.06 \times 10^{-4} \mathrm{M}$ exhibited nearly no cytotoxicity on chondrocytes. Especially, ZXHA-C from $1.06 \times 10^{-8} \mathrm{M}$ to1.06 $\times 10^{-6} \mathrm{M}$ promoted cell growth evidently. In contrast, ZXHA-C at the concentrations of $1.06 \times 10^{-3} \sim 54.5 \times 10^{-3} \mathrm{M}$ showed an inhibitive effect on chondrocytes growth. Therefore, the concentrations of ZXHA-C ranged from $1.06 \times 10^{-8} \mathrm{M}$ to $1.06 \times 10^{-6} \mathrm{M}$ were chosen for further investigation. The cytotoxicity of TGF- $\beta 1$ was showed in Fig. $2 \mathrm{~B}$, TGF- $\beta 1$ at the concentration of $15 \mathrm{ng} / \mathrm{mL}$ was promoted chondrocytes growth evidently.

Cell viability was tested by FDA/PI staining (Fig. 3). The results demonstrated that ZXHA-C exerted potent effect on survival of chondrocytes culture in vitro. The FDA/PI staining indicated that live cells in ZXHA-C groups were more than the ones in the negative control. The results implied that ZXHA-C has a positive effect on cell growth. Among the experimental groups, concentration of $1.06 \times 10^{-7} \mathrm{M}$ was superior to others, which showed little difference compared with positive control. Fig. 4 showed the morphology of articular chondrocytes cultured in vitro for 2, 4 and 6 days. The chondrocytes treated by ZXHA-C grew better compared with the negative control in the same period. More cell colonies that represent typical morphology of chondrocytes were found in ZXHA-C groups. Especially at the concentration of $1.06 \times 10^{-7} \mathrm{M}$, ZXHA-C facilitated cell proliferation more than others, that was closed to positive control group. Fig. 5 shows the actin filaments of chondrocytes 


\section{Cellular Physiology Cell Physiol Biochem 2015;37:1196-1209 \begin{tabular}{l|l} 
DOI: 10.1159/000430243 & O 2015 S. Karger AG, Basel
\end{tabular} and Biochemistry Published online: September 30, 2015 www.karger.com/cpb}

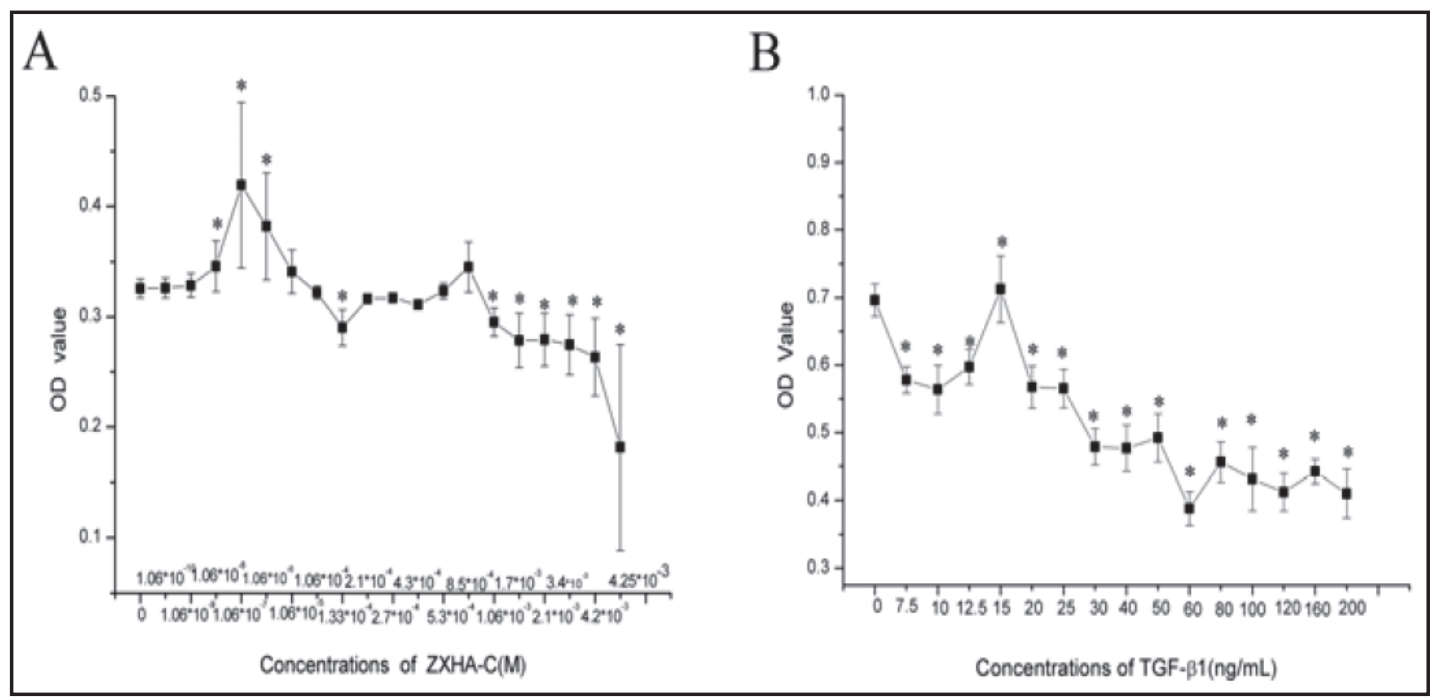

Fig. 2. Cytotoxicity of ZXHA-C (A) and TGF- $\beta 1$ (B) on chondrocytes after 3 days (mean $\pm S D, n=5$ ).

Fig. 3. (A) Confocal laser scanning microscopy images showing the viability of chondrocytes cultured in vitro alone (Control) or with ZXHA-C $\left(1.06 \times 10^{-8} \mathrm{M}\right.$, $\left.1.06 \times 10^{-7} \mathrm{M}, 1.06 \times 10^{-6} \mathrm{M}\right)$ and TGF- $\beta 1$ (T=15 ng/mL) for 2,4 and 6 days . Cell seeding density: $2 \times 10^{4} / \mathrm{mL}$ (original magnification $\times 40$, scale bar was $100 \mu \mathrm{m})$. (B) Cell number calculated and analyzed on the basis of FDA/PI staining images. Cell numbers were counted in one image by using the "cell calculating" toolbar in the Nikon A1 software. The data represent the mean \pm SD. of three independent culture experiments. Bars with different letters are significantly different from each other at $\mathrm{P}<0.05$.
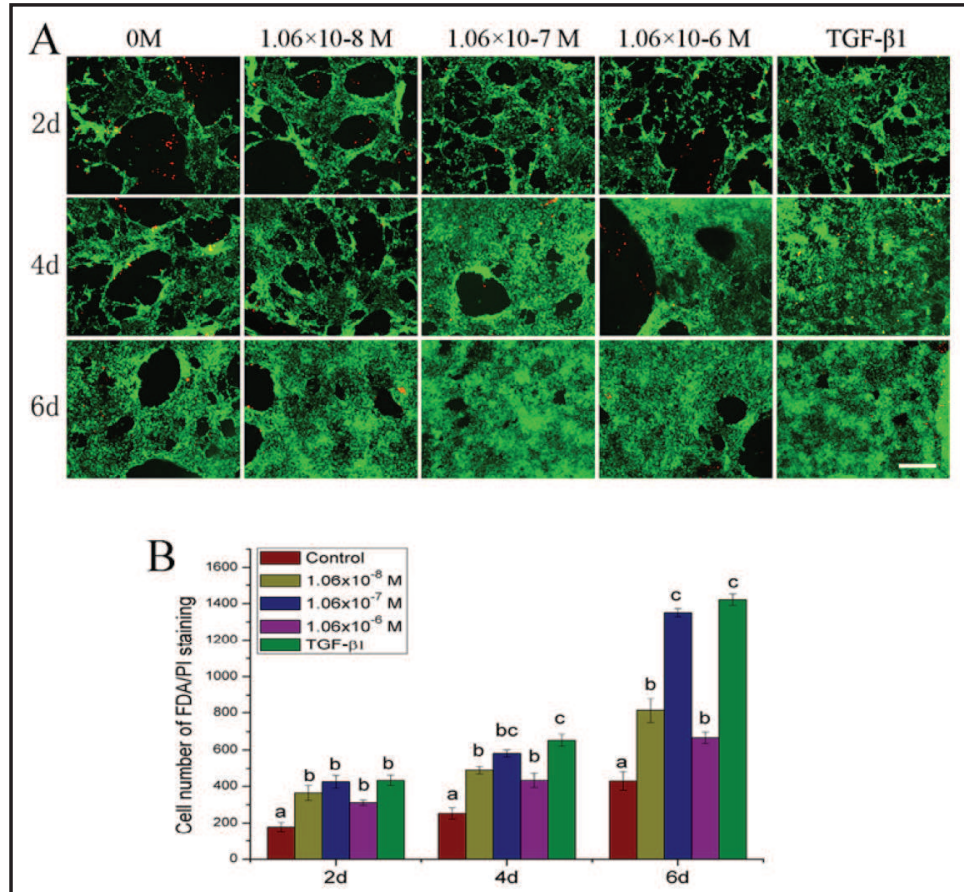

by the rhodamine phalloidin/Hoechst 33258 staining, the result of which was in agreement with the HE analysis. It was shown that cells in ZXHA-C treated groups grew in clumps with densely distributed extracellular matrix (ECM). Particularly, ZXHA-C of $1.06 \times 10^{-7} \mathrm{M}$ exhibited much denser ECM than other concentrations.

Biochemical assays were used for the quantitative determination of DNA and GAG production after 2, 4 and 6 days of culture. Cell proliferation of ZXHA-C- treated groups, TGF- $\beta 1$ group and negative control group were analyzed by DNA content measurements at 2, 4 and 6 days respectively. As shown in Fig. 6A, chondrocytes cultured with ZXHA-C grew faster than negative control, which was evidenced by the significantly higher DNA contents $(\mathrm{P}<0.05)$ in the same culture period. The results also indicated that ZXHA-C at the concentration of $1.06 \times 10^{-7} \mathrm{M}$ promoted cell growth the most in all the ZXHA-C groups, which was close to TGF- $\beta 1$ group. The histogram showed the GAG production given as a ratio of GAG 


\section{Cellular Physiology Cell Physiol Biochem 2015;37:1196-1209 \begin{tabular}{|l|l|l|l|l|l}
\hline DOI: 10.1159/000430243 & o 2015 S. Karger AG, Basel
\end{tabular} and Biochemistry Published online: September 30, 2015 www.karger.com/cpb}

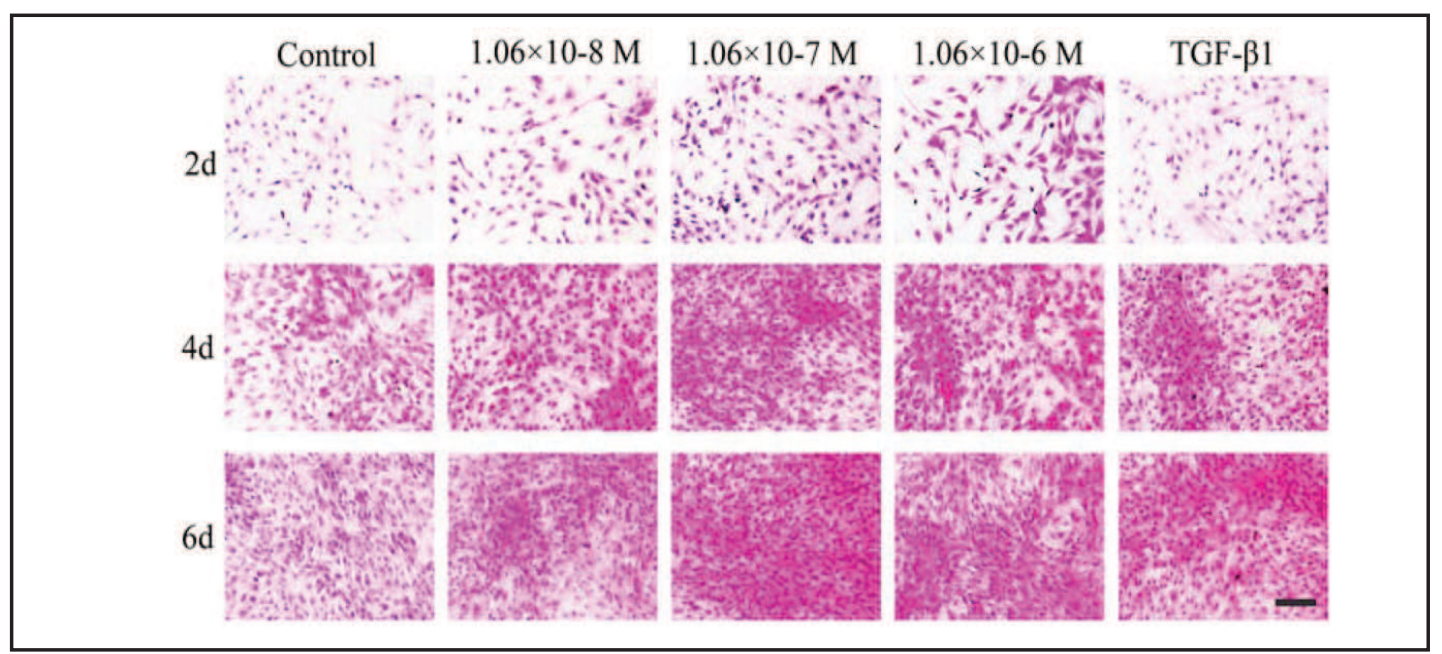

Fig. 4. Hematoxylin-eosin staining images showing the morphology of chondrocytes cultured in vitro alone (Control) or with ZXHA-C $\left(1.06 \times 10^{-8} \mathrm{M}, 1.06 \times 10^{-7} \mathrm{M}, 1.06 \times 10^{-6} \mathrm{M}\right)$ and TGF- $\beta 1$ (T=15 ng/mL) for 2, 4 and 6 days. Cell seeding density: $2 \times 10^{4} / \mathrm{mL}$ (original magnification $\times 200$, scale bar was $100 \mu \mathrm{m}$ ).

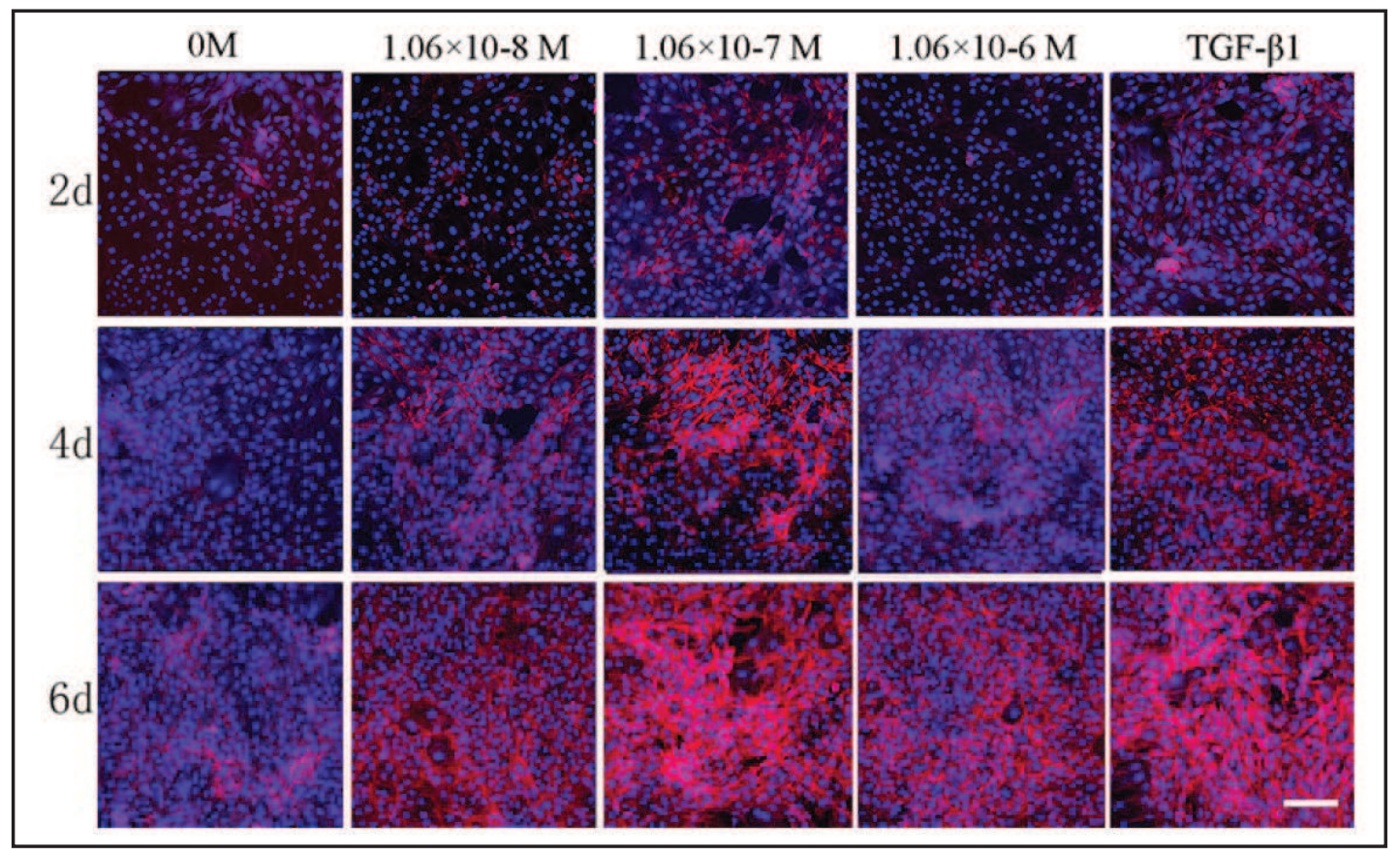

Fig. 5. Phalloidin/Hoechst 33258 staining images showing the morphology of chondrocytes cultured in vitro alone (Control) or with ZXHA-C $\left(1.06 \times 10^{-8} \mathrm{M}, 1.06 \times 10^{-7} \mathrm{M}, 1.06 \times 10^{-6} \mathrm{M}\right)$ and TGF- $\beta 1(\mathrm{~T}=15 \mathrm{ng} / \mathrm{mL})$ for 2, 4 and 6 days. Cell seeding density: $2 \times 10^{4} / \mathrm{mL}$ (original magnification $\times 100$, scale bar was $100 \mu \mathrm{m}$ ).

to DNA in culture media with different concentrations of ZXHA-C (Fig. 6B). Quantitatively, GAG production in ZXHA-C-treated groups was significantly enhanced than that in negative control at the same time point. The effect of ZXHA-C is dose-dependent, with $1.06 \times 10^{-7} \mathrm{M}$ at the peak which approximated to positive control. Qualitative assessment by using safranin- 0 staining also showed a deeper staining in ZXHA-C groups compared with negative control group (Fig. 7). ZXHA-C at concentration of $1.06 \times 10^{-7} \mathrm{M}$ exhibited the most GAG synthesis among the three concentrations, approached to TGF- $\beta 1$ group.

The effect of ZXHA-C on chondrocytes relative gene expression of collagen I, II, and X, Sox9, aggrecan (a proteoglycan composed of GAGs) after 2, 4 and 6 days culture was detected by realtime-PCR. As shown in Fig. 8, aggrecan, collagen II and Sox9 were notably promoted

\section{KARGER}




\section{Cellular Physiology Cell Physiol Biochem 2015;37:1196-1209 \begin{tabular}{l|l} 
DOI: 10.1159/000430243 & O 2015 S. Karger AG, Basel
\end{tabular} and Biochemistry Published online: September 30, 2015 www.karger.com/cpb}

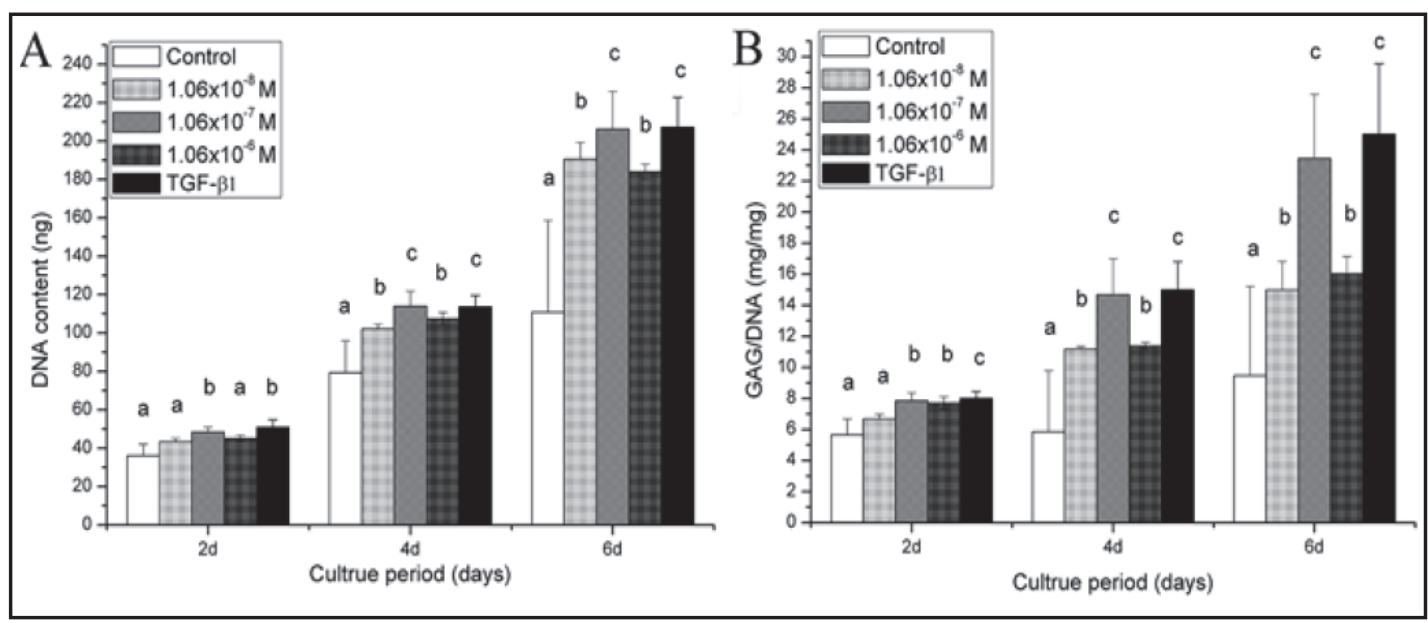

Fig. 6. Quantification of cell proliferation (DNA) and matrix production (glycosaminoglycan (GAG)) of cells by biochemical assays: (A) the proliferation of chondrocytes cultured in vitro alone (Control) or with ZXHA-C $\left(1.06 \times 10^{-8} \mathrm{M}, 1.06 \times 10^{-7} \mathrm{M}, 1.06 \times 10^{-6} \mathrm{M}\right)$ and TGF- $\beta 1$ (T=15 ng/mL) for 2,4 and 6 days; (B) GAG (mg) normalized to DNA (mg). Data from six independent experiments were evaluated, and the mean \pm SD is shown. Bars with different letters are significantly different from each other at $\mathrm{P}<0.05$.

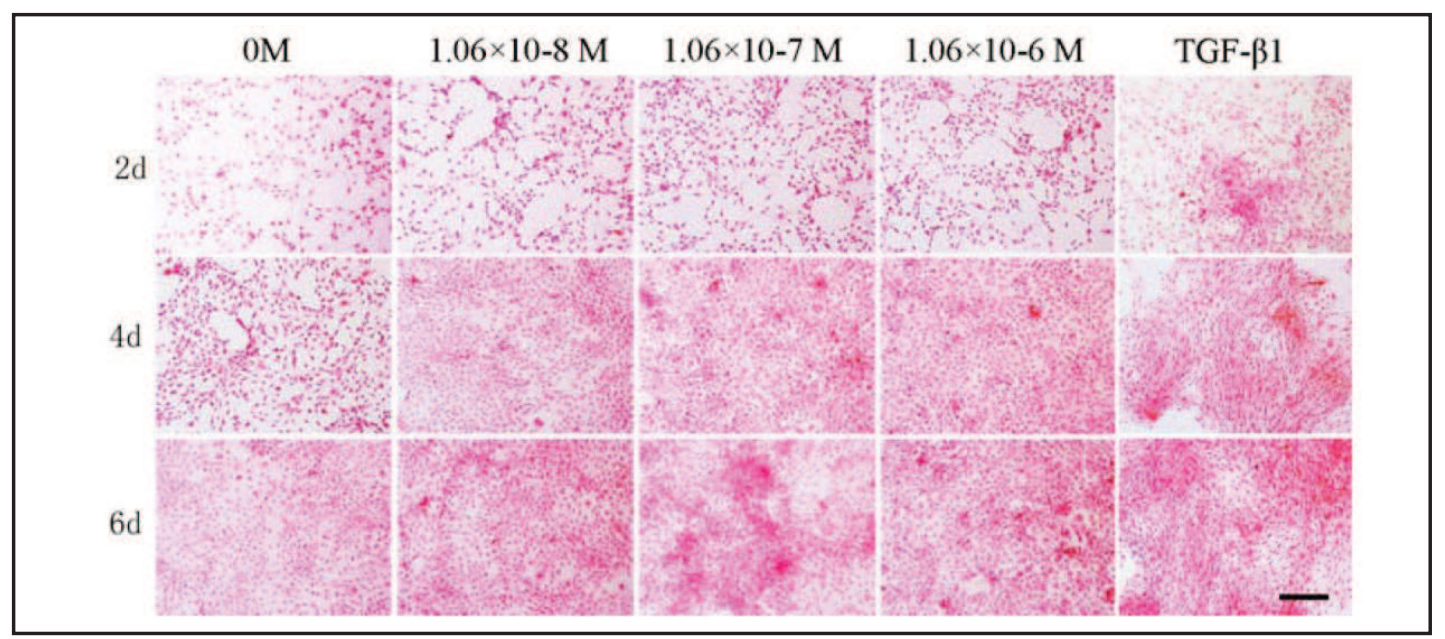

Fig. 7. Safranin 0 staining showing the ECM synthesis of chondrocytes culture in vitro alone (Control) or with ZXHA-C $\left(1.06 \times 10^{-8} \mathrm{M}, 1.06 \times 10^{-7} \mathrm{M}, 1.06 \times 10^{-6} \mathrm{M}\right)$ and TGF- $\beta 1(\mathrm{~T}=15 \mathrm{ng} / \mathrm{mL})$ for 2,4 and 6 days. Cell seeding density: $2 \times 10^{4} / \mathrm{mL}$ (original magnification $\times 100$, scale bar was $100 \mu \mathrm{m}$ ).

by ZXHA-C. Particularly, ZXHA-C at concentration of $1.06 \times 10^{-7} \mathrm{M}$ showed the highest collagen II, aggrecan and Sox 9 expression, among which some were even higher than positive control. The results indicated that ZXHA-C could up-regulate gene expressions collagen II, aggrecan and Sox9. In contrast, type I collagen was down-regulated by ZXHA-C. The results suggested that ZXHA-C may either delay or prevent the chondrocytes from dedifferentiation, acting the same role as TGF- $\beta 1$. In addition, collagen $\mathrm{X}$ expression was scarcely detectable in all groups, which suggested that cell hypertrophy could not be detected. Among all the groups, ZXHA-C at concentration of $1.06 \times 10^{-7} \mathrm{M}$ showed the best overall performance, as demonstrated by the highest expression of aggrecan and collagen II expression and the lowest collagen I expression. Expression of type I and type II collagen by immunohistochemical staining with and without ZXHA-C-treated culture medium was shown in Fig. 9. Large areas of positive staining for cartilage-specific type II collagen was shown in Fig. 9B, while only very sparse 


\section{Cellular Physiology Cell Physiol Biochem 2015;37:1196-1209 \begin{tabular}{l|l|l}
\hline DOI: 10.1159/000430243 & O 2015 S. Karger AG, Basel
\end{tabular} and Biochemistry Published online: September 30, 2015 www.karger.com/cpb}

Fig. 8. Quantitative comparison of ECM-related gene expression was detected by qRT-PCR. The chondrocytes were cultured alone (Control) or with ZXHA-C $(1.06$ $\times 10^{-8} \mathrm{M}, 1.06 \times 10^{-7} \mathrm{M}, 1.06$ $\left.\times 10^{-6} \mathrm{M}\right)$ and TGF- $\beta 1(\mathrm{~T}=15$ $\mathrm{ng} / \mathrm{mL}$ ) for (A) 2 days, (B) 4 days and (C) 6 days ( $n=3$ for each experiment). The gene expression levels in ZXHA-C media relative to the control group were analysed by the $2^{-\Delta \Delta C T}$ method using GAPDH as the internal control. The data represent the mean $\pm \mathrm{SD}$ of three independent culture experiments. Bars with different letters are significantly different from each other at $\mathrm{P}<0.05$.

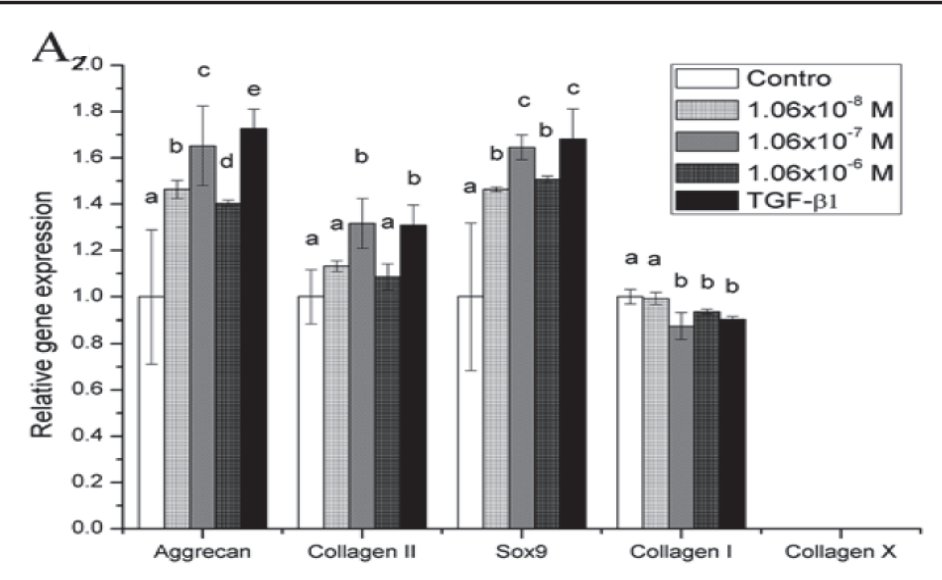

B

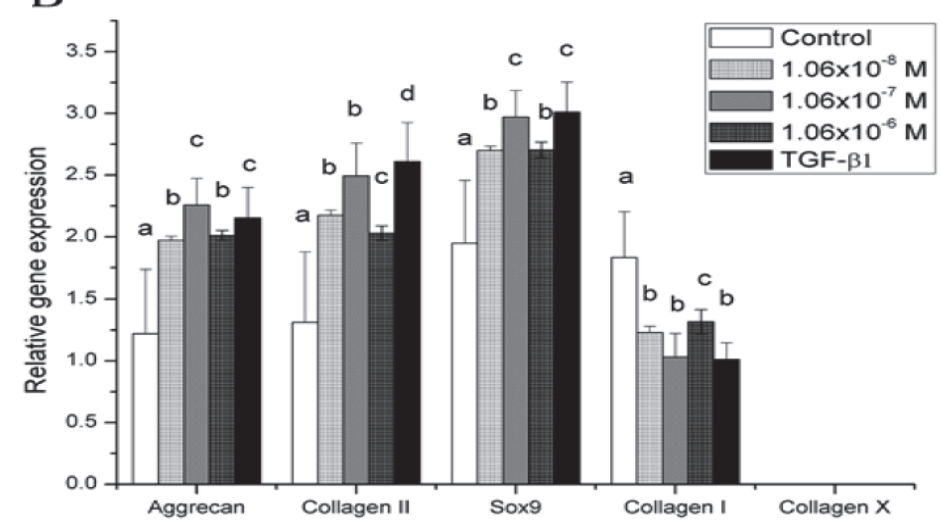

$\mathrm{C}$

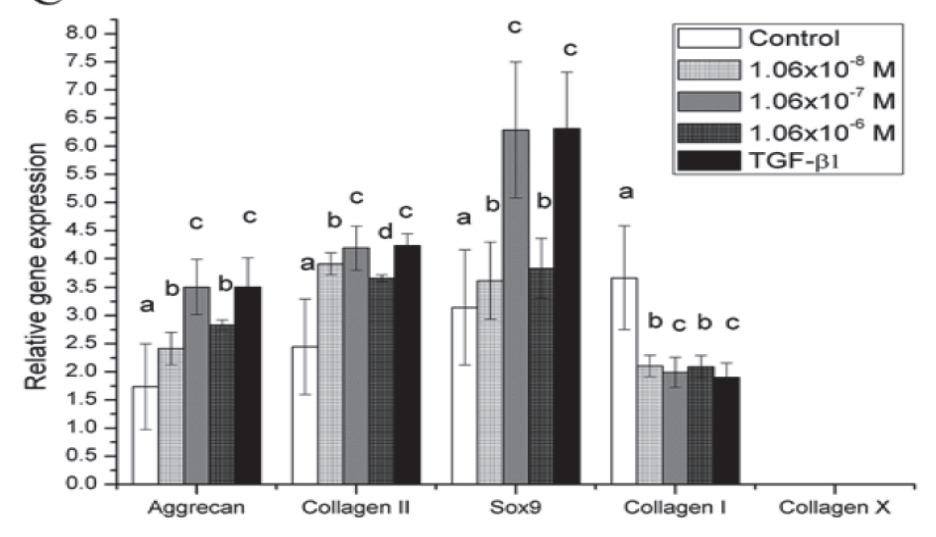

and light staining for type I collagen was observed (Fig. 9A) in ZXHA-C-treated groups, also positive control done. It is converse in negative control group. The results confirmed the maintenance of chondrocytic phenotype after treated with ZXHA-C (especially at concentration of $1.06 \times 10^{-7} \mathrm{M}$ ), which indicated that ZXHA-C may replace TGF- $\beta 1$ to effectively inhibit de-differentiation of chondrocytes cultured in vitro.

To determine the effect of ZXHA-C on the Wnt/ $\beta$-catenin signaling pathway in chondrocytes, we used qRT-PCR to examine the mRNA expression of cyclin D1, $\beta$-catenin, Frizzled-2, Wnt-4 and GSK-3 $\beta$ (Fig. 10). Compared to negative control group, ZXHA-C upregulate the expression of cyclin D1, $\beta$-catenin, Frizzled-2, Wnt- 4 and decrease the expression of GSK-3 $\beta$, similarly to the TGF- $\beta 1$ group. In addition, the immunohischemistry staining of $\beta$-catenin indicates that ZXHA-C and TGF- $\beta 1$ accelerated $\beta$-catenin nuclear translocation 


\begin{tabular}{|c|c|c|}
\hline م & Cell Physiol Biochem 2015;37:1196-1209 & \\
\hline and Biochemistry & $\begin{array}{l}\text { DOI: 10.1159/000430243 } \\
\text { Published online: September 30, } 2015\end{array}$ & $\begin{array}{l}\text { (c) } 2015 \text { S. Karger AG, Basel } \\
\text { www.karger.com/cpb }\end{array}$ \\
\hline
\end{tabular}

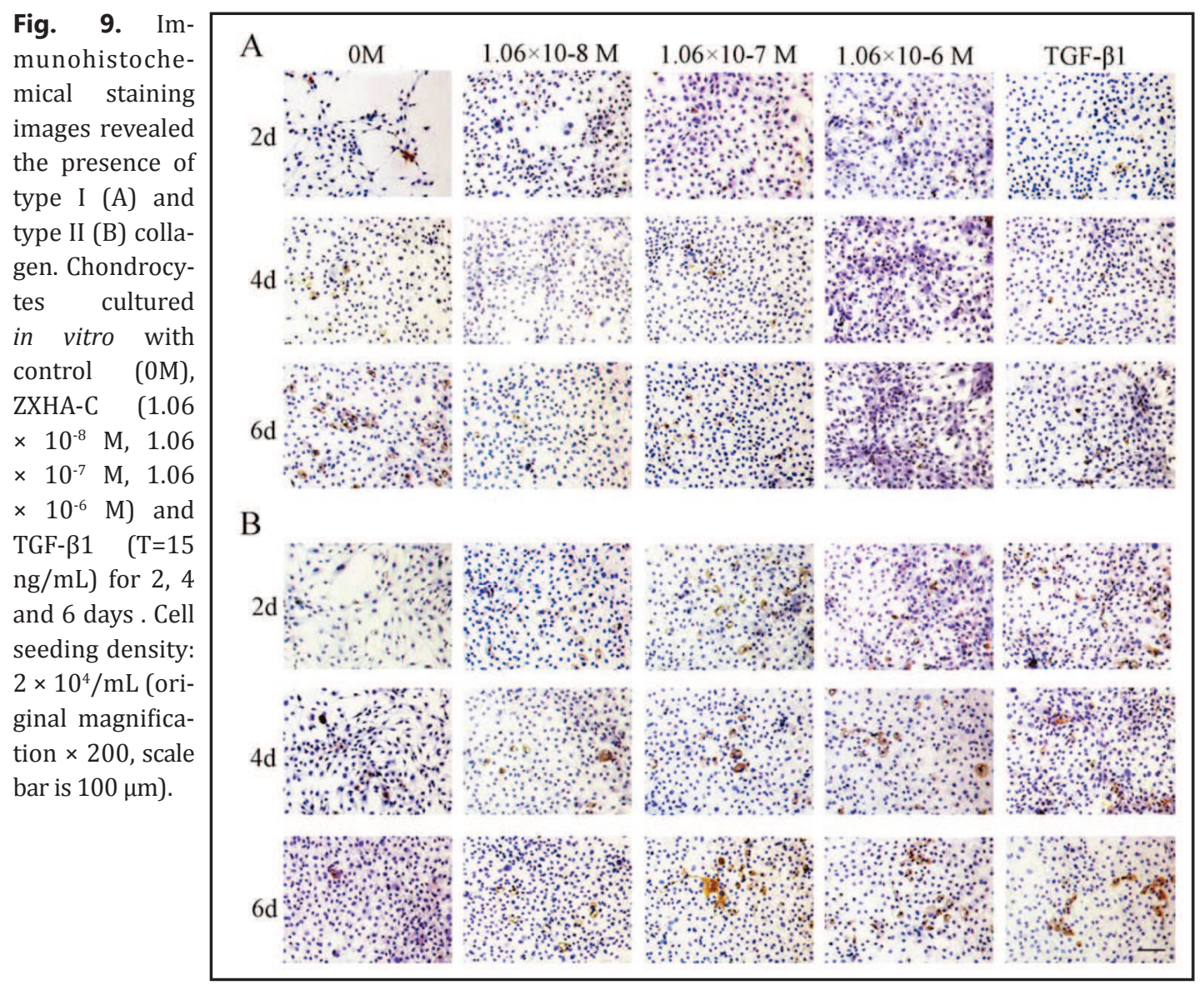

(Fig. 10B), while $\beta$-catenin positive staining only showed a litter in cytoplasm in the negative control group.

\section{Discussion}

The amount of autologous chondrocytes is too limited for the transplantation purpose. And chondrocytes are easy to lose phenotype that may impair the cartilage regeneration. Traditional growth factors were effective in preventing of dedifferentiation of chondrocytes and promoting of cell growth $[19,20]$. But they are too expensive and easy to lose activity. Therefore, to find the substitute agent is of significance. It has been reported that derivatives of GA appeared to play an important role in protection of chondrocytes. In this study, ZXHA-C was synthesized by coupling sulfonamide groups with GA and its effects on the chondrocytes growth and phenotype maintenance were investigated. The results indicated that ZXHA-C could accelerate chondrocytes growth, as evidenced by more rapid cell proliferation compared with negative control (Fig. 6A). ZXHA-C could obviously promote GAGs deposition in cultured chondrocytes which was shown by biochemical assay (Fig. 6B). As the main component of cartilage matrix, GAG is crucial in maintaining cartilage load-bearing capacity [21]. As consistent with the increase of GAG production, the expression of aggrecan, collagen II and Sox9 were up-regulated by ZXHA-C (Fig. 8). Sox9 was considered as the primary chondrogenic marker that enhanced the production of collagen and aggrecan [22] and acted a key role in chondrogenesis [23]. Especially at the dose of $1.06 \times 10^{-7} \mathrm{M}$, ZXHA-C showed the similar results as TGF- $\beta 1$ done. The results suggested that ZXHA-C could facilitate chondrocytes growth and stimulate exuberant cartilage matrix secretion through regulating the key activator of the chondrocyte-specific enhancer. 


\section{Cellular Physiology Cell Physiol Biochem 2015;37:1196-1209

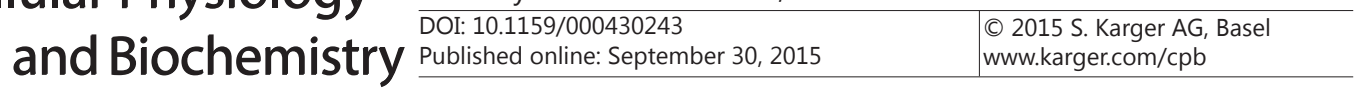

Fig. 10. (A) Quantitative comparison of $\mathrm{Wnt} / \beta$ catenin signaling pathway-related gene expression was detected by qRT-PCR The chondrocytes were cultured alone (Control) or with ZXHA-C $\left(1.06 \times 10^{-8} \mathrm{M}, 1.06 \times 10^{-7}\right.$ $\left.\mathrm{M}, 1.06 \times 10^{-6} \mathrm{M}\right)$ and TGF- $\beta 1$ ( $\mathrm{T}=15 \mathrm{ng} / \mathrm{mL}$ ). Bars with different letters are significantly different from each other at $\mathrm{P}<0.05$. (B) Immunohistochemical staining images revealed the presence of $\beta$-catenin. Cell seeding density: $2 \times 10^{4}$ / $\mathrm{mL}$ (original magnification $\times 200$, scale bar is 100 $\mu \mathrm{m})$.

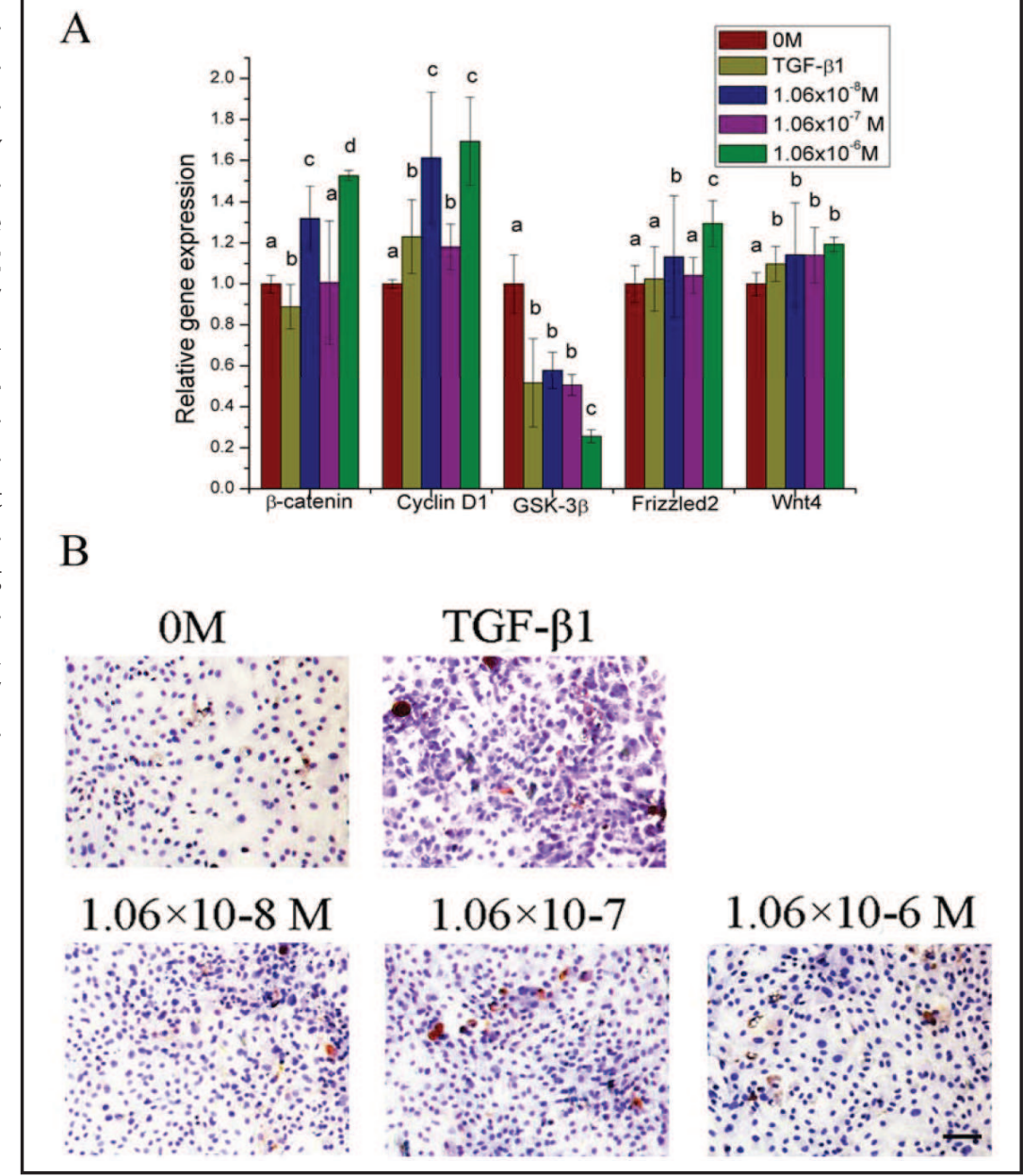

A

B

Dedifferentiation occurred when type II collagen and cartilage-specific proteoglycan is lost and replaced by a complex collagen phenotype consisting predominately of type I collagen and a low level of proteoglycan synthesis [24, 25]. Results of PCR, biochemical and immunohistochemical assay all showed down-regulation of collagen type I in ZXHA-C groups, which suggested that ZXHA-C could effectively delay or prevent dedifferentiation of chondrocytes. On the other hand, collagen type X that is specifically associated with hypertrophic process of chondrocytes and precedes the onset of endochondral ossification could not be detected in all the ZXHA-C-treated groups. This implied that hypertrophy of chondrocytes would not be induced by ZXHA-C. It should be noted that similar results were obtained between ZXHA-C at concentration of $1.06 \times 10^{-7} \mathrm{M}$ and positive control. Therefore, ZXHA-C has the ability to maintain the phenotype of chondrocytes, as proved by the reduced collagen I messages and the barely evident messages of collagen type X indicate the inhibition of the dedifferentiation and hypertrophy, which may be potential candidate as substitute of TGF- $\beta 1$.

Further study showed that unlike GA, the novel compound activated the Wnt/ $\beta$-catenin signaling pathway, which plays a crucial role in the regulation of cell proliferation [26]. In the process of cell growth, $\beta$-catenin accumulates in the cytosol followed by the activation of Wnt/ $\beta$-catenin signaling pathway. After translocates to the nucleus, $\beta$-catenin binds to the transcription factors [27] which promote cell cycle progression by regulating the expression of cyclin D1.Wnt signaling is related to the maintenance of chondrocytes by wnt-5a and wnt-5b (non-canonical pathway)by promoting the degradation of beta-catenin [28]. The misexpression of Wnt-5a delays the maturation of chondrocytes and the onsets in bone collar 


\section{Cellular Physiology Cell Physiol Biochem 2015;37:1196-1209 \begin{tabular}{c|c}
\hline DOI: 10.1159/000430243 & (c) 2015 S. Karger AG, Basel
\end{tabular} \begin{tabular}{l|l} 
and Biochemistry Published online: September 30, 2015 & www.karger.com/cpb \\
\hline
\end{tabular} \\ Lu et al.: ZXHA-C Exert Chondro-Protective Effect}

formation, while misexpression of Wnt-4 promotes these two processes. Beta-catenin is involved in mediating the positive regulatory effect of Wnt-4 [29] to accelerate chondrocytes maturation and bone formation [30].Our study showed that ZXHA-C up-regulated the expression of Wnt-4, which may inhibit Wnt5a binding with Fzd2. The combination of Wnt5a and Fzd2 may lead to the up-regulation of Gsk3b to further suppress $\beta$-catenin expression [31].These findings indicated that ZXHA-C activates the Wnt/ $\beta$-catenin signaling pathway by inhibiting GSK-3 $\beta$ to promote the translocation of non-phosphorylated $\beta$-catenin into the nucleus to enhance cyclin D1 expression.

Among the various concentrations of ZXHA-C, it was shown that a range between $1.06 \times$ $10^{-10} \mathrm{M}$ to1.06 $\times 10^{-4} \mathrm{M}$ was associated with the enhancement of chondrocytes proliferation (Fig. 2A). Among the chosen concentrations, ZXHA-C at the concentration of $1.06 \times 10^{-7} \mathrm{M}$ could support the greatest cell proliferation and stimulate the most matrix secretion, which is close to the positive control.

Due to inferior pharmacological effects and biological property of GA [32-35], the modification is of significance. As one of the derivatives of GA, Epigallocatechin-3-gallate (EGCG) was reported with the effect of inhibiting the degradation of human cartilage proteoglycan and type II collagen, and selectively inhibited ADAMTS-1, ADAMTS-4, and ADAMTS-5 [36, 37]. It was also found that EGCG ameliorates IL-1 $\beta$-mediated suppression of TGF- $\beta 1$ synthesis, and enhance type II collagen and aggrecan core protein synthesis in human articular chondrocytes [16]. In this study, ZXHA-C which is a novel derivative of GA, can also support the chondrocytes growth and maintain the phenotype. This may be associated with its activation of Wnt/ $\beta$-catenin signaling pathway which was inhibited by GA. The results implied that suitable modification of GA may lead to the improvement of the pharmacological and biological effects.

\section{Acknowledgments}

This work has been financially supported by Guangxi scientific Research and Technological Development Foundation (Grant No. Guikehe 14125008-2-14), Guangxi Science Fund for Distinguished Young Scholars (Grant No. 2014GXNSFGA118006). This work has been supported by Research Center for Regenerative medicine and Collaborative Innovation Center of Guangxi Biological Medicine.

\section{Disclosure Statement}

The authors confirm that this article content has no conflicts of interest.

\section{References}

1 Chung C, Burdick JA: Engineering cartilage tissue. Adv Drug Deliv Rev 2008;60:243-262.

2 Hu N, Wang C, Liang X, Yin L, Luo X, Liu B, Zhang H, Shui W, Nan G, Wang N, Wu N, Chen X, He Y, Wen S, Deng F, Zhang H, Liao Z, Luu HH, Haydon RC, He TC, Huang W: Inhibition of histone deacetylases potentiates BMP9-induced osteogenic signaling in mouse mesenchymal stem cell. Cell Physiol Biochem 2013;32:486498.

3 Diederichs S, Zachert K, Raiss P, Richter W: Regulating Chondrogenesis of human mesenchymal stromal cells with a retinoic acid receptor-beta inhibitor: differential sensitivity of chondral versus osteochondral development. Cell Physiol Biochem 2014;33:1607-1619.

4 Chua KH, Aminuddin BS, Fuzina NH, Ruszymah BH: Insulin-transferrin-selenium preventhuman chondrocyte dedifferentiation and promote the formation of high quality tissue engineered human hyaline cartilage. Eur Cell Mater 2005;9:58-67. 


\section{Cellular Physiology Cell Physiol Biochem 2015;37:1196-1209 \begin{tabular}{ll|l} 
and Biochemistry & $\begin{array}{l}\text { DOI: 10.1159/000430243 } \\
\text { Published online: September 30, } 2015\end{array}$ & $\begin{array}{l}\text { ○ 2015 S. Karger AG, Basel } \\
\text { www.karger.com/cpb }\end{array}$ \\
\hline
\end{tabular}}

Lu et al.: ZXHA-C Exert Chondro-Protective Effect

5 Loty S, Sautier JM, Forest N: Phenotypic modulation of nasal septal chondrocytes bycytoskeleton modification. Biorheology 2000;37:117-125.

6 Homicz MR, Schumacher BL, Sah RL, Watson D: Effects of serial expansion of septalchondrocytes on tissueengineered neocartilage composition. Ophtha IPlast Reconstr Surg 2002;127:398-408.

7 Mukaida T, Urabe K, Naruse K, Aikawa J, Katano M, Hyon SH, Itoman:. Influence of three-dimensional culture in a type II collagen sponge on primary cultured and dedifferentiatedchondrocytes. J Orthop Sci 2005;10:521-528.

8 Shang L, Qin J, Chen LB, Liu BX, Jacques M, Wang H: Effects of sodium ferulate on humanosteoarthritic chondrocytes and osteoarthritis in rats. Clin Exp Pharmacol Physiol 2009;36:912-918.

9 Angus KT Wann, JitenMistry, Emma J Blain, Adina T Michael-Titus, and Martin M Knigh: Eicosapentaenoic acid and docosahexaenoic acid reduce interleukin-1beta-mediated cartilagedegradation. Arthritis Res Ther 2010;12:R207.

10 Lu Z, Nie G, Belton PS, Tang H, Zhao B: Structure-activity relationship analysis of antioxidantability and neuroprotective effect of gallic acid derivatives. Neurochem Int 2006;48:263-274.

11 Panico AM, Cardile V, Avondo S, Garufi F, Gentile B, Puglia C, Bonina F, Santagati NA, RonsisvalleG: The in vitro effect of a lyophilized extract of wine obtained from Jacquez grapes on humanchondrocytes. Phytomedicine 2006;13:522-526.

12 Ou TT, Lin MC, Wu CH, Lin WL, Wang CJ: Gallic Acid Attenuates Oleic Acid-inducedProliferation of Vascular Smooth Muscle Cell Through Regulation of AMPK-eNOS-FAS Signaling. Curr Med Chem 2013;20:39443953.

13 Su TR, Lin JJ, Tsai CC, Huang TK, Yang ZY, Wu Mo, Zheng YQ, Su CC, Wu YJ: Inhibition of melanogenesis by gallic acid: possible involvement of the P13K/Akt and Wnt/ $\beta$-catenin signaling pathways in B16F10 cells. Int J Mol Sci 2013;14:20443-20458.

14 Aman A, Nguyen M and Piotrowski T: Wnt/ $\beta$-catenin dependent cell proliferation underlies segmented lateral line morphogenesis. Dev Biol 2011;349:470-482.

15 Saxena HO, Faridi U, Srivastava S, Kumar JK, Darokar MP, Luqman S, Chanotiya CS, Krishna V,Negi AS, Khanuja SP: Gallic acid-based indanone derivatives as anticancer agents. Bioorg Med Chem Lett 2008;18:3914-3918.

16 Andriamanalijaona R, Kypriotou M, Baugé C, Renard E, Legendre F, Raoudi M, BoumedieneK,Gatto H, Monginoux P, Pujol JP: Comparative effects of 2 antioxidants, selenomethionine andepigallocatechingallate, on catabolic and anabolic gene expression of articular chondrocytes. J Rheumatol 2005;32:19581967.

17 Nuti E, Santamaria S, Casalini F, Yamamoto K, Marinelli L, La Pietra V, Novellino E, Orlandini E, Nencetti S, Marini AM, Salerno S, Taliani S, Da Settimo F,Nagase H, Rossello A: Arylsulfonamide inhibitors of aggrecanases as potential therapeutic agents for osteoarthritis: Synthesisand biological evaluation. Eur J Med Chem 2013;62:379-394.

18 Kim YJ, Sah RL, Doong JY, Grodzinsky AJ: Fluorometric assay of DNA in cartilage explant susing Hoechst 33258. Anal Biochem 1988;174:168-176.

19 Ishibashi H, Nariai Y, Kanno T, Onimaru M, Sekine J: Effects of transforming growth factorbeta 1 on the plasminogen activation system, collagen and integrin synthesis, and proliferation of rabbitmandibular condylar chondrocytes. Int J Oral Maxillofac Surg 2014;43:470-475.

20 Gu Y1, Wang Y, Dai H, Lu L, Cheng Y, Zhu W: Chondrogenic differentiation of caninemyoblasts induced by cartilage-derived morphogenetic protein- 2 and transforming growth factor- $\beta 1$ in vitro. Mol Med Report 2012;5:767-772.

21 Robinson D, Ash H, Yayon A, Nevo Z, Aviezer D: Characteristics of cartilage biopsies used forautologous chondrocytes transplantation. Cell Transplant 2001;10:203-208.

22 Tew SR, Li Y, Pothacharoen P, Tweats LM, Hawkins RE, Hardingham TE: Retroviraltransduction with SOX9 enhances re-expression of the chondrocyte phenotype in passagedosteoarthritic human articular chondrocytes. Osteoarthritis Cartilage 2005;13:80-89.

23 Varghese S, Hwang NS, Canver AC, Theprungsirikul P, Lin DW, Elisseeff J: Chondroitin sulfatebased niches for chondrogenic differentiation of mesenchymal stem cells. Matrix Biol 2008;27:12-21

24 Benya PD, Shaffer JD: Dedifferentiated chondrocytes reexpress the differentiated collagenphenotype when cultured in agarose gels. Cell 1982;30:215-224. 


\section{Cellular Physiology Cell Physiol Biochem 2015;37:1196-1209

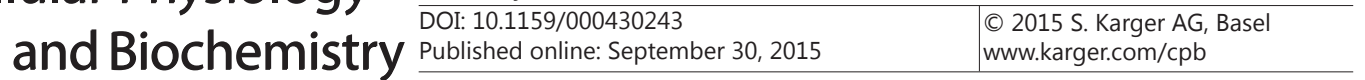

Lu et al.: ZXHA-C Exert Chondro-Protective Effect

25 Karlsen TA, Shahdadfar A, Brinchmann JE: Human primary articular chondrocytes, chondroblasts-like cells, and dedifferentiated chondrocytes: differences in gene, microRNA, and protein expression and phenotype. Tissue Eng Part C Methods 2011;17:219-227.

26 Tao HY, HeB, Liu SQ Wei AL, Tao FH, Tao HL, Deng WX, Li HH, Chen Q: Effect of carboxymethylated chitosan on the biosynthesis of NGF and activation of the Wnt/ $\beta$ catenin signaling pathway in the proliferation of Schwann cells. Eur J Pharmacol 2013;02:85-92.

27 Teo JL and Kahn M: The Wnt signaling pathway in cellular proliferation and differentiation: a tale of two coactivators. Adv Drug Deliv Rev 2010;62:1149-1155.

28 Hartmann C, Tabin CJ: Dual roles of wnt signaling during chondrogenesis in the chicken limb. Development 2000;127:3141-3159.

29 Topol L, Jiang X, Choi H, Garrett-Beal L, Garolan PL, Yang Y: Wnt-5a inhibits the canonical Wnt pathway by promoting GSK-3-independent beta-catenin degradation. J Cell Biol 2003;162:899-908.

30 Kitaqaki J, Iwamoto M, Liu JG, Tamamura Y, Pacifci M, Enomoto-Iwamoto M: Activation of beta-cateninLEF/TCF signal pathway in chondrocytes stimulates ectopic endochondral ossification. Osteoarthritis Cartilage 2003;11:36-43.

31 Jiang T, Zhou B, Huang L, Wu H, Huang J, Liang T, Liu H, Zheng L, Zhao J: Andrographolide exerts proosteogenic effect by activation of Wnt/ $\beta$-Catenin signaling pathway in Vitro. Cell Physiol Biochem 2015;36:2327-2339.

32 Kang MS, Jang HS, Oh JS, Yang KH, Choi NK, Lim HS, Kim SM: Effects of methyl gallateand gallic acid on the production of inflammatory mediators interleukin -6 and interleukin- 8 by oralepithelial cells stimulated with Fusobacteriumnucleatum. J Microbiol 2009;47:760-767.

33 Ho HH, Chang CS, Ho WC, Liao SY, Wu CH, Wang CJ: Anti-metastasis effects of gallic acidon gastric cancer cells involves inhibition of NF- $\mathrm{KB}$ activity and downregulation of PI3K/AKT/smallGTPase signals. Food ChemToxicol 2010;48:2508-2516.

34 Kuppan G, Balasubramanyam J, Monickaraj F, Srinivasan G, Mohan V, Balasubramanyam M: Transcriptional regulation of cytokines and oxidative stress by gallic acid in human THP-1 monocytes. Cytokine 2010;49:229-234.

35 Lo C, Lai TY, Yang JS, Yang JH, Ma YS, Weng SW, Lin HY, Chen HY, Lin JG, Chung JG: Gallicacid inhibits the migration and invasion of A375. S2 human melanoma cells through the inhibition ofmatrix metalloproteinase-2 and Ras. Melanoma Res 2011;21:267-273.

36 Adcocks C1, Collin P, Buttle DJ: Catechins from green tea (Camellia sinensis) inhibit bovineand human cartilage proteoglycan and type II collagen degradation in vitro. J Nutr 2002;132:341-346.

37 Vankemmelbeke MN, Jones GC, Fowles C, Ilic MZ, Handley CJ, Day AJ, Knight CG, Mort JS, Buttle DJ: Selective inhibition of ADAMTS-1, -4 and -5 by catechingallate esters. Eur J Biochem 2003;270:2394-2403. 